\title{
Fumigant toxicity of allyl isothiocyanate to populations of the red flour beetle Tribolium castaneum
}

\author{
J.C. Santos ${ }^{a}$, L.R.A. Faroni ${ }^{b}$, A.H. Sousa ${ }^{a}$, R.N.C. Guedes ${ }^{a, *}$ \\ ${ }^{a}$ Departamento de Biologia Animal, Universidade Federal de Viçosa, Viçosa, MG 36570-000, Brazil \\ ${ }^{\mathrm{b}}$ Departamento de Engenharia Agrícola, Universidade Federal de Viçosa, Viçosa, MG 36570-000, Brazil
}

\section{A R T I C L E I N F O}

Article history:

Accepted 21 March 2011

\section{Keywords:}

Allyl isocyanate

Biofumigant

Mustard oil

Respiration rate

Susceptibility

\begin{abstract}
A B S T R A C T
The phasing out of methyl bromide as a fumigant, the phosphine resistance problems in stored product insect-pests, and the ever-growing concerns with human health and environmental safety have been guiding the search of alternative fumigants. Allyl isothiocyanate (AITC) is the main component of mustard oil with reported pesticide activity and potential as a fumigant of stored foodstuffs. The fumigant toxicity of AITC was assessed in adults of 18 populations of the red flour beetle Tribolium castaneum (Coleoptera: Tenebronidae). These populations were all susceptible to AITC with negligible variation among them. Two of these populations were further used to test the AITC susceptibility of eggs, larvae (early and late instars), and pupae of T. castaneum. All of the developmental stages of both populations were similarly susceptible to AITC. No cross-resistance between phosphine and AITC was observed. Despite the significant variation in body mass, respiration rate, and fitness among the populations of T. castaneum, they were not correlated with AITC susceptibility. Larvae and adult malformations were observed when larvae and pupae were exposed to AITC. These results show the potential of AICT as an alternative fumigant against stored product insects.
\end{abstract}

(C) 2011 Elsevier Ltd. All rights reserved.

\section{Introduction}

Fumigants play a major role in stored product protection, but unlike residual pesticides where new compounds have become available and continue to do so, the development of new fumigants have not been forthcoming (Bell, 2000; Zettler and Arthur, 2000). Of the two fumigants in widespread use, methyl bromide is an ozonedepletor and is being phased out as agreed through the Montreal Protocol (Montreal Protocol on Substances that Deplete the Ozone Layer, 1994; Bell, 2000). The other fumigant, phosphine, has some issues with insecticide resistance, requires air-tight conditions necessary for its desired efficacy, and it is under regulatory review in several countries because of environmental and human safety concerns (Champ and Dyte, 1976; Garry et al., 1989; Environmental Protection Agency, 1993; Anonymous, 1997; Chaudhry, 2000; Zettler and Arthur, 2000). Regarding new fumigants, sulphuryl fluoride is used in few countries with only recent use extension to food commodities and food handling facilities in the USA, Canada and Europe (Bell, 2000; Prabhakaran, 2006; Emekci, 2010). Consequentlly, there is a high level of interest in the development of new alternative fumigants for stored product protection.

\footnotetext{
* Corresponding author. Tel.: +55 (31) 3899 4008; fax: +55 (31) 38994012.

E-mail address: guedes@ufv.br (R.N.C. Guedes).
}

A recent focus of attention among alternative fumigants are the biofumigants, which reflects the growing attention received by biopesticides or biorational pesticides (Isman, 2006; Rajendran and Sriranjini, 2008; Rosell et al., 2008). Natural products, and particularly plant products, are potential new insecticides for crop protection as insecticides and chemical backbones for the synthesis of new insecticides (Kidd, 2000; Rajendran and Sriranjini, 2008). Among plants, cruciferous vegetables (including cabbage and mustard, among others) produce glucosinolates, which are secondary metabolites of plant defense involved in plant-plant, plant-microorganism, and plant-insect interactions (Chew, 1988; Mewis et al., 2002; Tsao et al., 2002; Agrawal and Kurashige, 2003; Müller, 2009). Glucosinolates are the storage form of isothiocyanates in the plants, which are released upon hydrolysis by thioglucosidase (=myrosinase) yielding an aglycone that, after undergoing non-enzymatic rearrangements, produces the said isothiocyanates (Chew, 1988; Tsao et al., 2002).

The use of green manure, crop residues and seed meals of Brassica plants (cruciferous vegetables) as biofumigants against soil pathogens and nematode suppression have been recognized (e.g., Zasada et al., 2009; Lu et al., 2010; Motisi et al., 2010). In addition, isothiocyanates generated by the glucosinolate-myrosinase system exhibits herbicide, bactericide and insecticide activity (Lin et al., 2000; Demirel et al., 2009; Hara et al., 2010). One of such isothiocynates, the allyl 
isothiocyanate (AITC) comes mainly from broken seeds of black mustard (Brassica nigra) or brown Indian mustard (Brassica juncea), and it is commercially produced by the reaction of allyl chloride and potassium thiocyanate (sometimes referred as synthetic mustard oil in this case) (Romanowski and Klenk, 2005). AITC is used as insecticide, bactericide, and nematicide possessing four active EPA registrations in the USA (Kegley et al., 2010).

Although AITC is available for foliar treatment against some insect species mainly for turf and ornamental plants in the US (Kegley et al., 2010), its fumigant activity has also been reported against adults of stored product insects (Worfel et al., 1997; Tsao et al., 2002; Wu et al., 2009). Here we further assessed the fumigant activity of AITC against adults of 18 populations of Tribolium castaneum (Herbst), the red flour beetle, some of which are resistant to phosphine (Pimentel et al., 2007; Sousa et al., 2008). This research aimed to determine: (1) AITC insecticidal activity on 18 populations of $T$. castaneum; (2) potential cross-resistance between AITC and phosphine; (3) AITC effect on immature stages of two populations of $T$. castaneum; (4) if insect body mass, respiration rate and fitness affect AITC toxicity; and (5) if AITC leads to potential insect malformations, since spiracle and crochet malformation were induced by isothiocyanates in the tobacco hornworm (Manduca sexta (Lepidoptera: Sphingidae)) (Ujváry et al., 1989).

\section{Material and methods}

\subsection{Insect populations and fumigant}

Eighteen populations of $T$. castaneum were used. They are representative populations collected between 2004 and 2007 from different stored product facilities from five Brazilian States; in addition two laboratory strains were also assessed (Table 1). Six of these populations (Bom Despacho, Campos de Júlio, Rio Verde, Uberlândia, Unaí-1, and Viçosa-1) were resistant to phosphine with resistance ratios ranging from 37.0- to 186.2-fold (Pimentel et al., 2007; Sousa et al., 2008). These strains are periodically monitored. Field populations ( $>250$ unsexed adults) were reared for at least two generations in standardized laboratory conditions before starting the bioassays. Insects were maintained in clear glass jars $(1.5 \mathrm{~L})$ at $26 \pm 2{ }^{\circ} \mathrm{C}, 75 \pm 5 \%$ r.h., and $24 \mathrm{~h}$ darkness. Ground maize kernels free of

Table 1

Origin of the Brazilian populations of Tribolium castaneum.

\begin{tabular}{|c|c|c|c|c|c|}
\hline $\begin{array}{l}\text { Code } \\
\text { no. }\end{array}$ & Site & State & Storage facility & Product & Month/Year \\
\hline 1 & Água Boa & MT & Warehouse & Maize & August 2004 \\
\hline 2 & Aguanil & MG & $\begin{array}{l}\text { Farm wood } \\
\text { store }\end{array}$ & $\begin{array}{l}\text { Maize } \\
\text { (in the curb) }\end{array}$ & May 2005 \\
\hline 3 & Barra do Garças & MG & Rice Mill & Rice & March 2007 \\
\hline 4 & Bom Despacho & MG & Metallic bin & Maize & May 2005 \\
\hline 5 & Bragança Paulista & SP & $\begin{array}{l}\text { Farm wood } \\
\text { store }\end{array}$ & Maize & March 2005 \\
\hline 6 & Campos de Júlio & MG & Metallic Bin & Maize & June 2005 \\
\hline 7 & Frutal & MG & Metallic Bin & Sorghum & December 2005 \\
\hline 8 & Guaxupé & MG & Metallic Bin & Maize & August 2005 \\
\hline 9 & Nova Era & MG & Warehouse & Maize & May 2005 \\
\hline 10 & Piracicaba & SP & Laboratory & Maize & August 2004 \\
\hline 11 & Picos & PI & Metallic Bin & Maize & February 2007 \\
\hline 12 & Rio Verde & GO & Metallic Bin & Maize & July 2005 \\
\hline 13 & Sacramento & MG & $\begin{array}{l}\text { Horizontal } \\
\text { bulk store }\end{array}$ & Maize & May 2005 \\
\hline 14 & Uberlândia & MG & Metallic Bin & Maize & August 2004 \\
\hline $15 a$ & Unaí I & MG & Metallic Bin & Maize & August 2004 \\
\hline $15 b$ & Unaí II & MG & Metallic Bin & Maize & July 2004 \\
\hline $16 a$ & Viçosa I & MG & Laboratory & Maize & March 2004 \\
\hline $16 b$ & Viçosa II & MG & $\begin{array}{l}\text { Animal food } \\
\text { industry }\end{array}$ & Maize & September 2004 \\
\hline
\end{tabular}

insecticide residues and with $13 \%$ moisture content (m.c.) were used as food substrate.

Commercial allyl isothiocyanate (AITC) was obtained from Petite Marie Química Fina (95\% pure; São Paulo, SP, Brazil), where it is produced by the reaction of allyl chloride and potassium thiocyanate, as commonly employed in the food industry. An AITC-soybean oil stock solution $(0.5 \% \mathrm{v} / \mathrm{v})$ was prepared for the fumigation bioassays. Soybean oil was used as solvent to minimize AITC sorption which would take place if applied to grains using a more volatile solvent (Paes et al., 2011).

\subsection{AITC toxicity bioassays}

AITC concentration-mortality curves for $T$. castaneum were established using the AITC concentration range of 2.25-5.62 $\mu \mathrm{L}$ a.i./L in $0.56 \mu \mathrm{L}$ a.i./L intervals. For the adult bioassays, AITC solutions in four dilutions were spread over filter paper $(0.1 \mathrm{~mL}$; Whatman no. 1 ; $2.25 \mathrm{~cm}^{2}$; four replicates), which were placed over a Petri dish $(5 \mathrm{~cm}$ diameter) at the bottom of a 0.8 L glass jar, and covered with organza to prevent direct insect contact with the oil solution containing AITC. Thirty non-sexed adults of $T$. castaneum (1-4 week old) were introduced and the jars were sealed with silicon (ORBIVED Neutro, Orbi Química Ltda, Leme, SP, Brazil) to prevent escape of fumigant. The exposure time was $24 \mathrm{~h}$ and the jars were maintained at the same environmental conditions as the insects were reared. Death was ascertained by lack of insect response after prodding with a fine hair brush. Soybean oil was used as a control. Four replicates (i.e., four jars with 30 insects each) were used for each AICT concentration and a minimum of four concentrations (in addition to the control) were used for each concentration-mortality bioassay.

For the immature bioassays, eggs (one to six days-old), early instar larvae (12 days-old), late instar larvae (18 days-old), and pupae (three to four days-old) from two populations of T. castaneum were used - Água Boa, which is susceptible to phosphine, and Bom Despacho, which is phosphine resistant (Pimentel et al., 2007). The immature stages were obtained from 500 non-sexed adults maintained in glass jars $(3.25 \mathrm{~L})$ containing $500 \mathrm{~g}$ dog food (Beneful ${ }^{\circledR}$, Purina, São Paula, SP, Brazil) as food substrate for $24 \mathrm{~h}$. This food source allows contrast with the insect eggs, which were sieved after six days (0.50 $\mathrm{mm}$ mesh), and inspected under stereomicroscope. The eggs were isolated and placed in Petri dishes ( $5 \mathrm{~cm}$ diameter) in groups of 30 providing them (if necessary) with ground maize kernel ( $30 \mathrm{~g}$ ) until the desired developmental stage for the bioassays. The bioassays were carried out as described for adult insects, without food provision and for $24 \mathrm{~h}$, after which the insects were again provided with ground maize kernel for seven days when mortality was assessed as above. The number of replicates and concentrations used were the same as for adults, as were the control treatments.

\subsection{Respiration rate, body mass and instantaneous rate of population growth $\left(r_{i}\right)$}

The respiration rate of adult insects was determined by their rate of $\mathrm{CO}_{2}$ production, as measured with a TR3C carbon dioxide analyzer (Sable System International, Las Vegas, USA), using the methods described by Sousa et al. (2008), adapted from Guedes et al. (2006). Briefly, 20 non-sexed adult insects were used for each $25 \mathrm{~mL}$ chamber, and three of such chambers (i.e., replicates) were used for each $T$. castaneum population. The insects were acclimated for $12 \mathrm{~h}$ within the chambers and $\mathrm{CO}_{2}$ production was assessed for $1 \mathrm{~h}$ using a current $\left(600 \mathrm{~mL} \mathrm{~min}^{-1}\right)$ of $\mathrm{CO}_{2}$-free air to purge the $\mathrm{CO}_{2}$ produced in each chamber, which was measured in a infra-red $\mathrm{CO}_{2}$ analyzer $\left(\mu \mathrm{L} \mathrm{h}^{-1}\right.$ insect $\left.{ }^{-1}\right)$. A control chamber without insects was simultaneously used as a control. After this measurement, the insects were removed from the flasks and 
Table 2

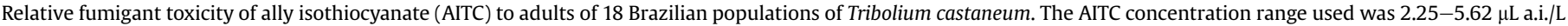
(24 h exposure).

\begin{tabular}{|c|c|c|c|c|c|c|c|c|}
\hline Population & No. of insects & Slope $( \pm$ SEM $)$ & $\mathrm{CL}_{50}(95 \% \mathrm{FL})\left(\mu \mathrm{L} \mathrm{L}^{-1}\right)$ & $\mathrm{RT}$ at $\mathrm{CL}_{50}(95 \% \mathrm{CI})$ & $\mathrm{CL}_{95}(95 \% \mathrm{FL})\left(\mu \mathrm{L} \mathrm{L}^{-1}\right)$ & RT at $\mathrm{CL}_{95}(95 \% \mathrm{CI})$ & $\chi^{2}$ & $P$ \\
\hline Água Boa & 480 & $23.38( \pm 2.00)$ & $4.42(4.35-4.49)$ & $1.18(1.14-1.22)$ & $5.20(5.07-5.38)$ & $1.01(0.96-1.07)$ & 2.67 & 0.26 \\
\hline Aguanil & 600 & $19.18( \pm 1.34)$ & $4.01(3.94-4.08)$ & $1.07(1.03-1.11)$ & $4.89(4.76-5.06)$ & $0.95(0.90-1.01)$ & 3.81 & 0.28 \\
\hline Barra do Garças & 540 & $19.24( \pm 1.33)$ & $4.11(4.04-4.19)$ & $1.10(1.06-1.13)$ & $5.01(4.87-5.19)$ & $0.99(0.93-1.04)$ & 5.34 & 0.14 \\
\hline Bom Despacho & 570 & $20.17( \pm 1.42)$ & $4.14(4.06-4.21)$ & $1.10(1.06-1.13)$ & $4.99(4.87-5.16)$ & $0.98(0.93-1.03)$ & 5.07 & 0.16 \\
\hline Bragança Paulista & 540 & $13.05( \pm 0.92)$ & $4.28(4.17-4.37)$ & $1.14(1.10-1.18)$ & $5.72(5.50-6.00)$ & $1.12(1.05-1.19)$ & 5.07 & 0.16 \\
\hline Campos de Júlio & 390 & $17.00( \pm 1.32)$ & $4.43(4.33-4.53)$ & $1.18(1.14-1.22)$ & $5.53(5.34-5.79)$ & $1.08(1.02-1.15)$ & 5.74 & 0.12 \\
\hline Frutal & 510 & $17.94( \pm 1.26)$ & $4.32(4.23-4.40)$ & $1.15(1.11-1.19)$ & $5.33(5.18-5.53)$ & $1.04(0.99-1.10)$ & 2.98 & 0.39 \\
\hline Guaxupé & 480 & $19.61( \pm 1.53)$ & $4.01(3.92-4.09)$ & $1.07(1.03-1.11)$ & $4.86(4.72-5.04)$ & $0.95(0.90-1.00)$ & 5.54 & 0.13 \\
\hline Nova Era & 480 & $20.30( \pm 1.60)$ & $4.23(4.15-4.30)$ & $1.13(1.09-1.17)$ & $5.10(4.96-5.28)$ & $1.00(0.94-1.05)$ & 4.89 & 0.17 \\
\hline Piracicaba & 600 & $10.51( \pm 0.83)$ & $4.66(4.55-4.79)$ & $1.24(1.20-1.29)$ & $6.69(6.32-7.21)$ & $1.31(1.21-1.42)$ & 5.96 & 0.11 \\
\hline Picos & 570 & $11.72( \pm 0.87)$ & $4.15(4.05-4.25)$ & $1.11(1.07-1.15)$ & $5.73(5.49-6.07)$ & $1.12(1.05-1.20)$ & 0.89 & 0.82 \\
\hline Rio Verde & 330 & $15.07( \pm 1.37)$ & $4.45(4.33-4.56)$ & $1.18(1.14-1.23)$ & $5.72(5.48-6.06)$ & $1.12(1.04-1.19)$ & 3.70 & 0.29 \\
\hline Sacramento & 600 & $10.35( \pm 0.85)$ & $3.82(3.70-3.93)$ & $1.02(0.98-1.06)$ & $5.51(5.27-5.86)$ & $1.08(1.01-1.15)$ & 1.78 & 0.61 \\
\hline Uberlândia & 570 & $6.59( \pm 0.71)$ & $4.26(4.09-4.42)$ & $1.13(1.08-1.17)$ & $7.57(6.84-8.80)$ & $1.48(1.30-1.69)$ & 2.85 & 0.41 \\
\hline Unaí I & 480 & $11.20( \pm 1.09)$ & $4.17(4.04-4.29)$ & $1.11(1.07-1.16)$ & $5.84(5.52-6.34)$ & $1.14(1.05-1.24)$ & 2.98 & 0.39 \\
\hline Unaí II & 600 & $12.21( \pm 0.96)$ & $3.74(3.63-3.83)$ & - & $5.10(4.91-5.35)$ & - & 3.14 & 0.36 \\
\hline Viçosa I & 570 & $16.87( \pm 1.15)$ & $4.11(4.03-4.19)$ & $1.10(1.06-1.13)$ & $5.15(5.00-5.34)$ & $1.00(0.95-1.06)$ & 4.72 & 0.19 \\
\hline Viçosa II & 600 & $11.88( \pm 0.85)$ & $4.18(4.08-4.28)$ & $1.11(1.07-1.16)$ & $5.75(5.52-6.06)$ & $1.12(1.05-1.20)$ & 5.08 & 0.16 \\
\hline
\end{tabular}

individually weighed on an analytical balance (Sartorius BP 210D, Göttingen, Germany). Respiration rate and body mass were presented separately, without normalizing the first by the second since this procedure may mask the effect of the individual (Haynes, 2001). These same determinations were also carried out for immature stages of two populations of T. castaneum (Água Boa and Bom Despacho) using the same procedures.

Instantaneous rate of population growth $\left(r_{i}\right)$ was determined in Petri dishes $(14 \times 1 \mathrm{~cm})$ containing 40 g ground maize kernels $(13 \%$ m.c.) using ten replicates for each population. Twenty non-sexed adult insects (two to three weeks old) were released in each Petri dish and maintained at the same environmental conditions as the laboratory colonies for 60 days. After such period, the number of live insects was recorded and the $r_{i}$ was estimated following Walthall and Stark (1997) where $r_{\mathrm{i}}=\operatorname{Ln}\left(\mathrm{N}_{\mathrm{f}} / \mathrm{N}_{0}\right) / \Delta \mathrm{t}$ and $\mathrm{N}_{\mathrm{f}}$ is the final number of live insects, $\mathrm{N}_{0}$ is the initial number of (live) insects, and $\Delta t$ is the duration of the experiment.

\subsection{Statistical analysis}

The concentration-mortality data were subjected to probit analysis (PROC PROBIT; SAS Institute, 2009) and the confidence intervals for the toxicity ratios (TRs) were estimated following Robertson and Preisler (1992). The lethal concentrations (LC) were considered significantly different $(P<0.05)$ if their confidence limits did not include the value 1 . TRs for AITC were subject to correlation analysis against the phosphine resistance ratios earlier estimated (Pimentel et al., 2007) using the Correlation Procedure (PROC CORR) in SAS (SAS Institute, 2009). Not all of the populations screened here were used by Pimentel et al. (2007), therefore only those common to both studies were used in this correlation analysis.

The data of adult $\mathrm{CO}_{2}$ production and body mass, as well as rate of population growth were subjected to analysis of variance and Scott-Knott groupment analysis test, if appropriate (Scott and Knott, 1974; PROC GLM; SAS Institute, 2009). These data was also subjected to correlation analysis against AITC toxicity rate (PROC CORR; SAS Institute, 2009).

The results of $\mathrm{CO}_{2}$ production of the immature insects were subjected to a two-way analysis of covariance, with insect populations and developmental stages as independent variables and body mass as covariate, complemented by linear regression analysis when necessary (PROC GLM; SAS Institute, 2009).

\section{Results}

\subsection{AITC fumigant toxicity}

The probit model was suitable for the concentration-mortality data obtained with the populations of $T$. castaneum based on the low $\chi^{2}$ and high $P$-values obtained for each concentration-mortality curve $\left(\chi^{2}<5.7 ; P>0.05\right)$ (Tables 2 and 3$)$. The toxicity ratio of adults from the 18 populations of $T$. castaneum exhibited negligible variation among them ranging from 1.0 to 1.24 -fold at $\mathrm{LC}_{50}$ and from 0.95 to 1.48 -fold at $\mathrm{LC}_{95}$ (Table 2 ). Very few adult populations exhibited significantly reduced susceptibility and such significance was always marginal based on Robertson and Preisler (1992). In contrast, there was significant slope variation among strains, ranging from 10.3 to 23.4 , indicating heterogeneity of response

Table 3

Relative fumigant toxicity of ally isothiocyanate (AITC) to the delevopmental stages of two populations of Tribolium castaneum.

\begin{tabular}{|c|c|c|c|c|c|c|c|}
\hline Population & Developmental stage & No. of insects & Slope ( \pm SEM $)$ & $\mathrm{CL}_{50}(95 \% \mathrm{FL})\left(\mu{\left.\mathrm{L} . \mathrm{L}^{-1}\right)}\right.$ & RT at $\mathrm{CL}_{50}(95 \% \mathrm{CI})$ & $\chi^{2}$ & $\mathrm{P}$ \\
\hline \multirow[t]{5}{*}{ Água Boa } & Egg & 600 & $5.26( \pm 0.67)$ & $3.88(3.68-4.14)$ & - & 3.53 & 0.31 \\
\hline & Early instar & 540 & $5.45( \pm 0.70)$ & $4.54(4.33-4.77)$ & $1.17(1.08-1.26)$ & 4.96 & 0.17 \\
\hline & Late instar & 450 & $15.87( \pm 1.14)$ & $4.16(4.06-4.26)$ & $1.07(1.00-1.14)$ & 4.21 & 0.23 \\
\hline & Pupa & 570 & $10.60( \pm 0.85)$ & $4.30(4.19-4.41)$ & $1.10(1.04-1.18)$ & 3.73 & 0.29 \\
\hline & Adult & 420 & $23.38( \pm 2.00)$ & $4.42(4.35-4.49)$ & $1.13(1.07-1.20)$ & 2.67 & 0.26 \\
\hline \multirow[t]{5}{*}{ Bom Despacho } & Egg & 510 & $5.18( \pm 0.69)$ & $3.67(3.49-3.88)$ & - & 4.27 & 0.23 \\
\hline & Early instar & 510 & $5.51( \pm 0.77)$ & $4.63(4.42-4.88)$ & $1.25(1.17-1.35)$ & 4.96 & 0.17 \\
\hline & Late instar & 450 & $15.85( \pm 1.37)$ & $4.13(4.03-4.23)$ & $1.12(1.06-1.19)$ & 4.14 & 0.24 \\
\hline & Pupa & 570 & $13.04( \pm 0.96)$ & $4.44(4.34-4.54)$ & $1.20(1.14-1.27)$ & 4.46 & 0.21 \\
\hline & Adult & 570 & $20.17( \pm 1.42)$ & $4.14(4.06-4.21)$ & $1.12(1.06-1.18)$ & 5.07 & 0.16 \\
\hline
\end{tabular}


within some populations (e.g., Bom Despacho and Água Boa). Although some of the insect populations screened here are resistant to phosphine (as determined by Pimentel et al. (2007)), such resistance was not correlated with AITC susceptibility $(n=11$; $r=-0.05 ; P=0.87)$.

The concentration-mortality curves for the immature stages from the two most heterogeneous populations, Água Boa and Bom Despacho (which are susceptible and resistant to phosphine respectively), were also very similar among them, and even among developmental stages with marginally significant differences in toxicity rate based on their 95\% confidence interval (CI) (Table 3). There was little variation between populations (which was high for adults), but large variation among stages with eggs exhibiting the most homogeneous response and adults the most heterogeneous response.

\subsection{Respiration rate, body mass and instantaneous rate of population growth $\left(r_{i}\right)$}

The adult populations of $T$. castaneum differed significantly in respiration rate $\left(F_{17,36}=6.31, P<0.001\right)$, body mass $\left(F_{17,36}=4.74\right.$, $P<0.001)$, and also population growth rate $\left(F_{17,162}=8.59\right.$, $P<0.001$ ) (Table 4). However, none of these traits correlates significantly with susceptibility to AITC (TR at $\mathrm{LC}_{50}$ ) (respiration rate: $n=18, r=0.11, P=0.67$; body mass: $n=18, r=0.02, P=0.95$; and population growth rate: $n=18, r=0.28, P=0.26$ ).

Respiration rate was influenced by the insect developmental stages $\left(F_{1,22}=5.21, P=0.03\right)$ and its body mass $\left(F_{1,22}=22.86\right.$, $P<0.001)$, but not by populations $\left(F_{1,22}=0.01, P=0.97\right)$ and there was no significant interaction between these sources of variance of respiration rate $\left(F_{1,22}<2.91, P=0.10\right)$ based on the analysis of covariance. Respiration rate increased with body mass and also greatly differ with the developmental stage with only the pupa stage as outlayer (Fig. 1). Again none of these traits was significantly correlated with susceptibility of the different developmental stages to AITC (TR at $\mathrm{LC}_{50}$ ) (respiration rate: $n=10, r=0.09, P=0.81$; body mass: $n=10, r=0.36, P=0.310)$.

\subsection{Insect malformations}

Morphological abnormalities were observed in larva, pupa and adults of $T$. castaneum exposed to concentrations of AITC around the

\section{Table 4}

Insect respiration rate $\left(\mu \mathrm{LCO}_{2} \cdot \mathrm{h}^{-1}\right.$.insect $\left.{ }^{-1}\right)$, body mass $(\mathrm{mg})$ and instantaneous rate of population growth $\left(\mathrm{r}_{\mathrm{i}}\right)( \pm \mathrm{SEM})$ of (adult) insects from 18 populations of Tribolium castaneum. Means followed by the same letter within a column are not significantly different by Scott-Knott groupment analysis test $(P<0.05)$.

\begin{tabular}{llll}
\hline Population & $\begin{array}{l}\text { Respiration rate } \\
\left(\mu \mathrm{L} \mathrm{CO}_{2} \cdot \mathrm{h}^{-1} .\right.\end{array}$ & Body mass $(\mathrm{mg})$ & $\begin{array}{l}\text { Instantaneous } \\
\text { rate of population } \\
\text { inseto }\end{array}$ \\
& $\begin{array}{l}1.198 \pm 0.086 \mathrm{~b} \\
\text { growth }\left(\mathrm{r}_{\mathrm{i}}\right)\end{array}$ \\
\hline Água Boa & $0.930 \pm 0.075 \mathrm{c}$ & $1.923 \pm 0.002 \mathrm{a}$ & $0.025 \pm 0.003 \mathrm{a}$ \\
Aguanil & $0.710 \pm 0.039 \mathrm{c}$ & $1.795 \pm 0.020 \mathrm{~b}$ & $0.009 \pm 0.005 \mathrm{~d}$ \\
Barra do Garças & $1.267 \pm 0.092 \mathrm{~b}$ & $1.835 \pm 0.036 \mathrm{~b}$ & $0.014 \pm 0.003 \mathrm{c}$ \\
Bom Despacho & $0.793 \pm 0.306 \mathrm{c}$ & $1.950 \pm 0.053 \mathrm{a}$ & $0.012 \pm 0.009 \mathrm{c}$ \\
Bragança Paulista & $1.214 \pm 0.006 \mathrm{~b}$ & $1.981 \pm 0.017 \mathrm{a}$ & $0.024 \pm 0.006 \mathrm{a}$ \\
Campos de Júlio & $0.724 \pm 0.118 \mathrm{c}$ & $1.861 \pm 0.071 \mathrm{~b}$ & $0.014 \pm 0.005 \mathrm{c}$ \\
Frutal & $0.716 \pm 0.009 \mathrm{c}$ & $1.713 \pm 0.102 \mathrm{~b}$ & $0.028 \pm 0.002 \mathrm{a}$ \\
Guaxupé & $1.185 \pm 0.490 \mathrm{~b}$ & $2.048 \pm 0.041 \mathrm{a}$ & $0.021 \pm 0.003 \mathrm{~b}$ \\
Nova Era & $0.671 \pm 0.061 \mathrm{c}$ & $1.738 \pm 0.025 \mathrm{~b}$ & $0.013 \pm 0.005 \mathrm{c}$ \\
Piracicaba & $0.865 \pm 0.120 \mathrm{c}$ & $2.101 \pm 0.222 \mathrm{a}$ & $0.006 \pm 0.005 \mathrm{~d}$ \\
Picos & $1.024 \pm 0.142 \mathrm{c}$ & $1.870 \pm 0.033 \mathrm{~b}$ & $0.020 \pm 0.004 \mathrm{~b}$ \\
Rio Verde & $0.859 \pm 0.081 \mathrm{c}$ & $1.693 \pm 0.007 \mathrm{~b}$ & $0.016 \pm 0.005 \mathrm{c}$ \\
Sacramento & $0.654 \pm 0.120 \mathrm{c}$ & $1.970 \pm 0.053 \mathrm{a}$ & $0.019 \pm 0.003 \mathrm{~b}$ \\
Uberlândia & $1.739 \pm 0.387 \mathrm{a}$ & $1.996 \pm 0.052 \mathrm{a}$ & $0.013 \pm 0.004 \mathrm{c}$ \\
Unaí I & $0.724 \pm 0.043 \mathrm{c}$ & $1.816 \pm 0.005 \mathrm{~b}$ & $0.009 \pm 0.009 \mathrm{~d}$ \\
Unaí II & $0.717 \pm 0.057 \mathrm{c}$ & $1.818 \pm 0.035 \mathrm{~b}$ & $0.019 \pm 0.005 \mathrm{~b}$ \\
Viçosa I & $1.787 \pm 0.011 \mathrm{a}$ & $1.988 \pm 0.048 \mathrm{a}$ & $0.023 \pm 0.003 \mathrm{a}$ \\
\hline Viçosa II & & & \\
\hline
\end{tabular}

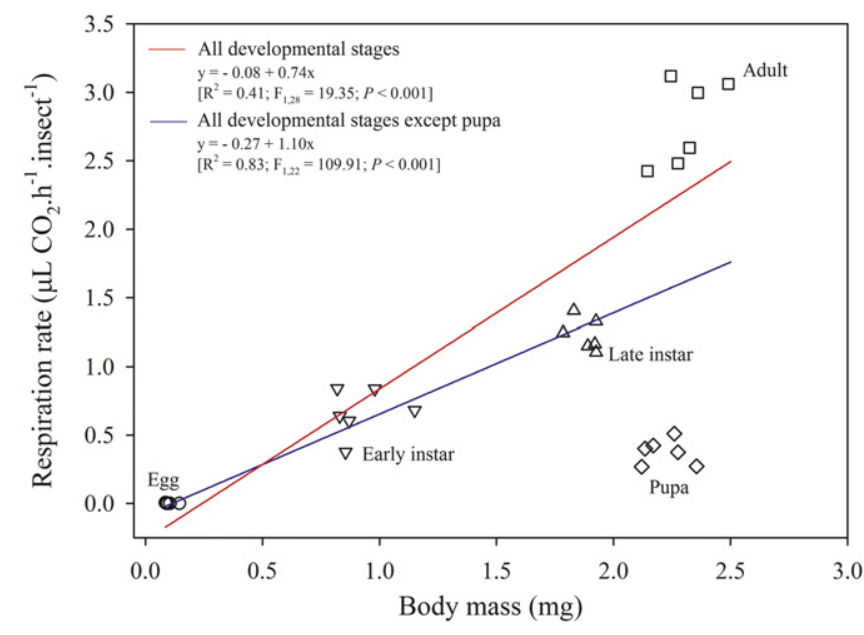

Fig. 1. Relationship between respiration rate $\left(\mu \mathrm{LCO}_{2} \cdot \mathrm{h}^{-1}\right.$. insect $\left.{ }^{-1}\right)$ and body mass $(\mathrm{mg})$ of individual insects from different developmental stages of the red flour beetle Tribolium castaneum. Each symbol represents the average determination of the 30 indivivuals encompassing each replicate (for each developmental phase from two insect populations). Two estimated regressions are exhibited, one including the pupal stage, and the other excluding it.

$\mathrm{LC}_{50}\left(4.50 \mu \mathrm{L} \mathrm{L}^{-1}\right)$. These abnormalities ranged from differences in sclerotization up to drastic abdominal malformations with a broader range of variation observed in adults generated from exposed pupa. Typical larva and adult malformations are exhibited in Fig. 2.

\section{Discussion}

The high toxicity of AITC to adults of T. castaneum were similar to other studies with the maize weevil Sitophilus zeamais, the lesser grain borer Rhyzopertha dominica, the book louse Liposcelis entomophila, the confused flour beetle Tribolium confusun and one other study with T. castaneum (Worfel et al., 1997; Demirel et al., 2009; Wu et al., 2009). All 18 populations of $T$. castaneum tested in our study, some of which are resistant to phosphine (Pimentel et al., 2007), were susceptible to AITC. In fact, AITC susceptibility was uniform among adults and immatures of T. castaneum, and our results were the first to be published for the immature stages. Furthermore, there was no correlation between phosphine resistance and susceptibility to AITC in T. castaneum indicating absence of cross-resistance between these compounds. The low variability of AITC susceptibility among the insect populations studied suggests that the defense mechanisms used for phosphine resistance are ineffective for AITC, as also observed for ozone (Sousa et al., 2008). However some populations of T. castaneum exhibited high heterogeneity of response to AITC (e.g., Água Boa e Bom Despacho, which are about twice as heterogeneous as other populations such as Piracicaba based on the slopes of the concentration-response curves), indicating their potential for future selection for reduced susceptibility (or resistance) to AITC.

Reduced respiration rate have been linked to phosphine resistance as a potential mechanism for reducing penetration in the insect body (Cotton, 1932; Chaudhry, 1997; Pimentel et al., 2007). Significant variation in respiration rate was also observed among adults and immatures of $T$. castaneum, which was similar to published results for ozone but not phosphine (Pimentel et al., 2007; Sousa et al., 2008). This variation was uncorrelated to AITC susceptibility, indicating that respiration rate does not seem to play any role in reducing AITC toxicity. Nonetheless this relationship may still exist, although undetected in our study due to the lack of interpopulational variation in AITC susceptibility among the insect 

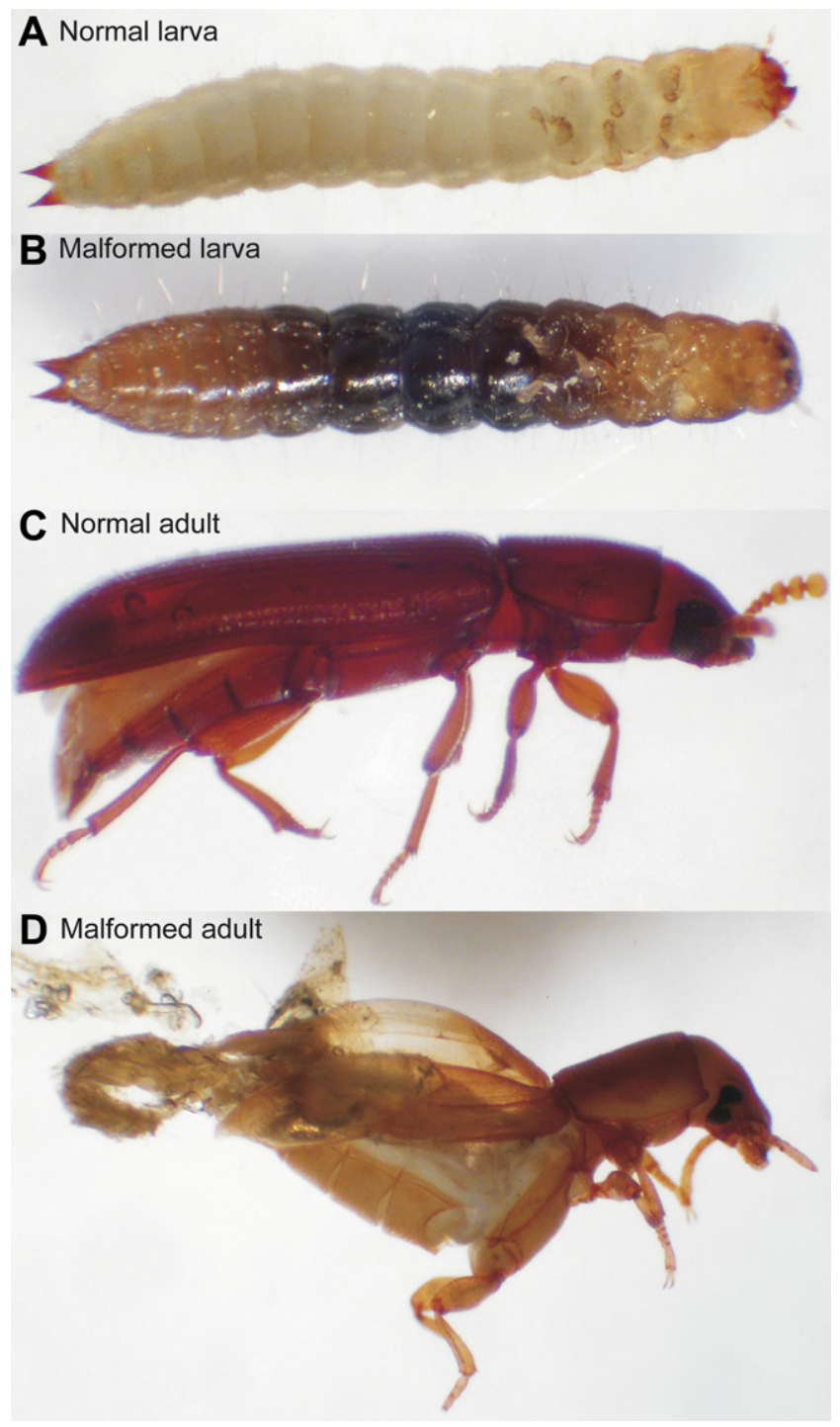

Fig. 2. Photos of normal (A, C) and malformed (B, D) larvae (A, B) and adults (C, D) of Tribolium castaneum when exposed to allyl isothiocyanate (AITC) at $4.50 \mu \mathrm{L} \mathrm{L}^{-1}$. The malformed larva was exposed to AITC for $24 \mathrm{~h}$ during the early larval stage (12 daysold), while the malformed adult was exposed to AITC for $24 \mathrm{~h}$ during the pupa stage.

populations studied. Body mass and population growth rate, which were related to fitness cost associated with insecticide resistance and its mitigation (Guedes et al., 2006; Oliveira et al., 2007; Corrêa et al., 2011), also varied among populations of T. castaneum and did not correlate with AITC susceptibility. Again, the lack of interpopulation variation in TR make their (potential) correlation with AITC susceptibility very difficult to detect.

Little is known about the mode of action underlying the insecticidal activity of glucosinolate breakdown products such as AITC. However, isothiocyanate compounds are generally regarded (1) as inactivators of the thiol group of essential enzymes (Hassall, 1990), and/or (2) as alkylating agents of nucleophilic groups of biopolymers such as DNA leading to cytotoxic properties that can affect the formation of the spiracular epidermis and crochet on the tobacco hornworm (Manduca sexta) prolegs, as observed with bis-isothicyanates (but not monoisothiocynates such as AITC) (Ujváry et al., 1989; Weber et al., 1992). In addition, bis-isothiocyanates exhibits juvenile hormone-like effects in caterpillars of the tobacco hornworm $M$. sexta, unlike mono-isothiocyanates such as AITC, which did not affect growth and development of this species (Ujváry et al., 1989). We did observe morphological malformation, particularly in adults when the immature stages (larvae and pupae) were exposed to AITC, suggesting that mono-isothiocyanates may also affect insect growth and development. Ujváry et al. (1989) may not have detected such effect because they have used topical applications and not inhalation as the exposure method, which is critical for evaluating fumigants such as AITC.

Glucosinolates are also reported to affect insect respiration, but the results are controversial. While these compounds from rapeseed led to inhibition of respiratory gas exchange reducing oxygen uptake in mitochondria and increasing the respiratory quotient $\left(\mathrm{RQ}=\mathrm{CO}_{2}\right.$ eliminate $/ \mathrm{O}_{2}$ consumed) without impairing food assimilation and growth of the yellow mealworm Tenebrio molitor (Pracros et al., 1992, 1997), distinct results were reported by Tsao et al. (2002) in cockroaches. AITC increased respiration rate (measured as $\mathrm{CO}_{2}$ emission) in the American and German cockroaches (Periplaneta americana and Blatella germanica respectively) exposed to this fumigant leading Tsao et al. (2002) to speculate on its possible (mode of) action as an uncoupler of the mitochondrial oxidative phosphorylation.

Our results with populations of $T$. castaneum did not show any correlation between respiration rate and AITC toxicity ratios (at $\mathrm{LC}_{50}$ ), and therefore does not provide support for Tsao's hypothesis of AITC acting as an unclouper of the oxidative phosphorylation (Tsao et al., 2002). However, Tsaos' work was based on cockroaches, which may exhibit distinct physiological response to AITC from $T$. castaneum. In addition, the use of soybean oil as solvent may have limited AITC evaporation reducing its potential effect on the respiration rate of $T$. castaneum and its fumigant efficacy against this species. Despite this, Pracros et al. $(1992,1997)$ also did not obtain any support for Tsao's hypothesis. In truth, our study provides evidence of AITC affecting insect growth and development based on the morphological malformations observed, but we need to grant that inhibition of gas exchange may also occur and may favor such malformations, what deserves future attention.

In conclusion, AITC exhibits homogeneous fumigant activity among different populations of $T$. castaneum. Such activity is not restricted to adults, but also to this species immature stages. No resistance to AITC was observed among the insect populations studied and there was no cross-resistance between AITC susceptibility and phosphine resistance suggesting the possibility of AITC use even against phosphine resistant insects as a management tactic. Respiration rate, body mass and population growth rate are not related to AITC susceptibility and adult malformation was observed when larvae and pupae were exposed to AITC. These results are suggestive of the potential of AICT as an alternative fumigant against stored product insects, but further studies to determine residue levels in kernel fractions with exposure time, temperature and cooking conditions are necessary, as are AITC stability under storage conditions among other studies.

\section{Acknowledgments}

Financial support provided by CAPES, CNPq and FAPEMIG were greatly appreciated, as was the technical assistance provided by O.D. Dhingra and A.M. Souza. The comments and suggestions provided by Dr. F. H. Arthur and the anonymous reviewers were greatly appreciated.

\section{References}

Agrawal, A.A., Kurashige, N.S., 2003. A role for isothiocyanates in plant resistance against the specialist herbivore Pieris rapae. Journal of Chemical Ecology 29, 1403-1415.

Anonymous, 1997. Parties of the Montreal Protocol on substances that deplete the ozone layer, Montreal, Canada. 
Bell, C.H., 2000. Fumigation in the 21st century. Crop Protection 19, 563-569.

Champ, B.R., Dyte, C.E., 1976. Report of the FAO Global Survey of Pesticide Susceptibility of Stored-Product Pests. FAO, Rome.

Chaudhry, M.Q., 1997. A review of the mechanisms involved in the action of phosphine as an insecticide and phosphine resistance in stored-product insects. Pesticide Science 49, 213-228.

Chaudhry, M.Q., 2000. Phosphine resistance: a growing threat to an ideal fumigant Pesticide Outlook 11, 88-91.

Chew, F.S., 1988. Biological effects of glucosinolates. In: Cutler, H.G. (Ed.), Biologically Active Natural Products: Potential Use in Agriculture. ACS, Washington, pp. 156-181.

Corrêa, A.S., Pereira, E.J.G., Cordeiro, E.M.G., Braga, L.S., Guedes, R.N.C., 2011. Physiological and behavioral resistance of Sitophilus zeamais to permethrin, esfenvalerate, and esfenvalerate + fenitrothion. Pest Management Science, in press.

Cotton, R.T., 1932. The relation of respiratory metabolism of insects to their susceptibility to fumigants. Journal of Economic Entomology 25, 1088-1103.

Demirel, N., Kurt, S., Gunes, U., Uluc, F.T., Cabuk, F., 2009. Toxicological responses of confused flour beetle, Tribolium confusum du Val (Coleoptera: Tenebrionoidea) to various isothiocyanate compounds. Asian Journal of Chemistry 21, 6411-6416.

Emekci, M., 2010. Quo vadis the fumigants? In: Carvalho, M.O., Fields, P.G. Adler, C.S., Arthur, F.H., Athanassiou, C.G., Campbell, J.F., Fleurat-Lessard, F., Flinn, P.W., Hodges, R.J., Isikber, A.A., Navarro, S., Noyes, R.T., Riudavets, J., Sinha, K.K., Thorpe, G.R., Timlick, B.H., Trematerra, P., White, N.D.G. (Eds.), Proceedings of the 10th International Working Conference on Stored Product Protection. JKI, Berlin, pp. 303-313.

Environmental Protection Agency, 1993. Regulatory Action under the Clean Air Act on Methyl Bromide. United States Environmental Protection Agency, Office of Air Radiation Strategic Protection Division, Washington, DC

Garry, V.F., Griffith, J., Danzl, T.J., Nelson, R.L., Whorton, E.B., Krueger, L.A. Cervenka, J., 1989. Human genotoxicity: pesticide applicators and phosphine. Science 246, 251-255.

Guedes, R.N.C., Oliveira, E.E., Guedes, N.M.P., Ribeiro, B., Serrão, J.E., 2006. Cost and mitigation of insecticide resistance in the maize weevil, Sitophilus zeamais Physiological Entomology 31, 30-38.

Hara, M., Yatsuzuka, Y., Tabata, K., Kuboi, T., 2010. Exogenously applied isothiocyanates enhance glutathione S-transferase expression in Arabidopsis but act as herbicides at higher concentrations. Journal of Plant Pathology 167, 643-649.

Hassall, K.A., 1990. The Biochemistry and Uses of Pesticides. MacMillan, London.

Haynes, J.P., 2001. Mass-specific and whole-animal metabolism are not the same concept. Physiological and Biochemical Zoology 74, 147-150.

Isman, M.B., 2006. Botanical insecticides, deterrents, and repellents in modern agriculture and an increasingly regulated world. Annual Review of Entomology $51,45-66$

Kegley, S.E., Hill, B.R., Orme, S., Choi, A.H., 2010. PAN Pesticide Database. Pesticide Action Network, San Francisco. www.pesticideinfo.org/Detail_Product.jsp?REG_ $\mathrm{NR}=06196600004 \&$ DIST_NR. [accessed 20.01.11].

Kidd, H., 2000. Human exposure to pesticide residues, natural toxins and GMOsreal and perceived risks. Pesticide Outlook 11, 215-216.

Lin, C.M., Kim, J., Du, W.X., Wei, C.I., 2000. Bacterial activity of isothiocyanate against pathogens onfresh produce. Journal of Food Protection 63, 25-30.

Lu, P.X., Gilardi, G., Gullino, M.L., Garibaldi, A., 2010. Biofumigation with Brassica plants and its effect on the inoculums potential of Fusarium yellows of Brassica crops. European Journal of Plant Pathology 126, 387-402.

Mewis, I., Ulrichs, C., Schnitzler, W.H., 2002. The role of glucosinolates and their hydrolysis products in oviposition and host-plant finding by cabbage webworm, Hellula undalis. Entomologia Experimentalis et Applicata 105, 129-139.

Montreal Protocol on Substances that Deplete the Ozone Layer, 1994. Report of the Methyl Bromide Technical Options Committee. 1995 Assessment. UNPE, Nairobi, Kenya.

Motisi, N., Dore, T., Lucas, P., Montfort, F., 2010. Dealing with the variation in biofumigation efficacy through an epidemiological framework. Soil Biology \& Biochemistry 42, 2044-2057.
Müller, C., 2009. Role of glucosinolates in plant invasiveness. Phytochemistry Reviews 8, 227-242.

Oliveira, E.E., Guedes, R.N.C., Tótola, M.R., De Marco Jr., P., 2007. Competition between insecticide-susceptible and -resistant populations of the maize weevil, Sitophilus zeamais. Chemosphere 67, 17-24.

Paes, J.L., Faroni, L.R.D.'A., Martins, M.A., Dhingra, O.D., Silva, T.A., 2011. Diffusion and sorption of allyl isothiocyanate in the process of fumigation of maize. Revista Brasileira de Engenharia Agrícola e Ambiental 15, 296-301.

Pimentel, M.A.G., Faroni, L.R.D.'A., Tótola, M.R., Guedes, R.N.C., 2007. Phosphine resistance, respiration rate and fitness consequences in stored-product insects. Pest Management Science 63, 876-881.

Prabhakaran, S., 2006. Commercial performance and global development status of ProFume $^{\circledR}$ gas fumigant. In: Lorini, I., Bacaltchuk, B., Beckel, H., Deckers, D., Sundfeld, E., Santos, J.P., Biagi, J.D., Celaro, J.C., Faroni, L.R.D.'A., Bortolini, L.O.F., Sartori, M.R., Elias, M.C., Guedes, R.N.C., Fonseca, R.G., Scussel, V.M. (Eds.), Proceedings of the 9th International Working Conference on Stored Product Protection. ABRAPÓS, Campinas, Brazil, pp. 635-641.

Pracros, P., Couranjou, C., Moreau, R., 1992. Effects on growth and respiration due to the ingestion of the rapeseed meal glucosinolates in young larvae of Tenebrio molitor. Comparative Biochemistry and Physiology Part A 103, 391-395.

Pracros, P., Couranjou, C., Moreau, R., Lavenseau, L., 1997. Consequences of rapeseed glucosinolate ingestion on the respiratory activity of fat body and isolated fat body mitochondria of Tenebrio molitor L. larvae (Coleoptera: Tenebrionidae). Annals of the Entomological Society of America 90, 138-148.

Rajendran, S., Sriranjini, V., 2008. Plant products as fumigants for stored-product insect control. Journal of Stored Products Research 44, 126-135.

Robertson, J.L., Preisler, H.K., 1992. Pesticide Bioassays with Arthropods. CRC, Boca Raton, FL, USA, p. 127.

Romanowski, F., Klenk, H., 2005. Thiocyanates and isothiocyanates, organic. In: Degussa, A.G. (Ed.), Ullmann's Encyclopedia of Industrial Chemistry. Wiley-VCH, Weinheim, Germany, pp. 749-759. doi:10.1002/14356007.a26_749.

Rosell, G., Quero, C., Coll, J., Guerrero, A., 2008. Biorational insecticides in pest management. Journal of Pesticide Science 33, 103-121.

SAS Institute, 2009. SAS/STAT 9.2 Useŕs Guide. SAS Institute, Cary, NC, USA.

Scott, A.J., Knott, M.A., 1974. A cluster analysis method for grouping means in the analysis of variance. Biometrics 30, 507-512.

Sousa, A.H., Faroni, L.R.D.'A., Guedes, R.N.C., Tótola, M.R., Urruchi, W.I., 2008. Ozone as a management alternative against phosphine-resistant insect pests of stored products. Journal of Stored Products Research 44, 379-385.

Tsao, R., Peterson, C.J., Coats, J.R., 2002. Glucosinolate breakdown products as insect fumigants and their effect on carbon dioxide emission of insects. BMC Ecology $2,1-7$.

Ujváry, I., Matolcsy, G., Riddiford, L.M., Hiruma, K., Horwath, K.L., 1989. Inhibition of spiracle and crochet formation and juvenile hormone activity of isothiocyanate derivatives in the tobacco hornworm, Manduca sexta. Pesticide Biochemistry and Physiology 35, 259-274.

Walthall, W.K., Stark, J.D., 1997. A comparison of acute mortality and population growth rate as endpoints of toxicological effect. Ecotoxicology and Environmental Safety 37, 45-52.

Weber, B., Martin, D., Otto, D., 1992. Novel insecticidal effects of isothiocyanate compounds. In: Otto, D., Weber, B. (Eds.), Insecticides: Mechanism of Action and Resistance. Intercept, Andover, UK, pp. 63-73.

Worfel, R.C., Schneider, K.S., Yang, T.C.S., 1997. Suppressive effect of allyl isothiocyanate on populations of stored grain insect pests. Journal of Food Processing and Preservation 21, 9-19.

Wu, H., Zhang, G.A., Zeng, S.Y., Lin, K.C., 2009. Extraction of allyl isothiocyanate from horseradish (Armoracia rusticana) and its fumigant insecticidal activity on four stored-product pests of paddy. Pest Management Science 65, 1003-1008.

Zasada, I.A., Meyer, S.L.F., Morra, M.J., 2009. Brassicaceous seed meals as soil amendments to suppress the plant-parasitic nematodes Pratylenchus penetrans and Meloidogyne incognita. Journal of Nematology 41, 221-227.

Zettler, J.L., Arthur, F.H., 2000. Chemical control of stored product insects with fumigants and residual treatments. Crop Protection 19, 577-582. 